\title{
Effects of Stubble Management on Soil Fertility and Crop Yield of Rainfed Area in Western Loess Plateau, China
}

\author{
G. B. Huang, ${ }^{1}$ Z. Z. Luo, ${ }^{2}$ L. L. Li, ${ }^{1}$ R. Z. Zhang, ${ }^{2}$ G. D. Li, ${ }^{3}$ L. Q. Cai, ${ }^{2}$ and J. H. Xie ${ }^{1}$ \\ ${ }^{1}$ Gansu Provincial Key Laboratory of Arid Land Crop Science/Faculty of Agronomy, Gansu Agricultural University, \\ Lanzhou 730070, China \\ ${ }^{2}$ Faculty of Resource and Environmental Science, Gansu Agricultural University, Lanzhou 730070, China \\ ${ }^{3}$ E H Graham Centre for Agricultural Innovation (Alliance between NSW Department of Primary Industries \\ and Charles Sturt University), Wagga Wagga Agricultural Institute, PMB, Wagga Wagga, NSW 2650, Australia
}

Correspondence should be addressed to G. B. Huang, huanggb@gsau.edu.cn

Received 14 June 2011; Revised 1 August 2011; Accepted 15 August 2011

Academic Editor: David C. Weindorf

Copyright (C) 2012 G. B. Huang et al. This is an open access article distributed under the Creative Commons Attribution License, which permits unrestricted use, distribution, and reproduction in any medium, provided the original work is properly cited.

\begin{abstract}
The combination of continuous cereal cropping, tillage and stubble removal reduces soil fertility and increases soil erosion on sloping land. The objective of the present study was to assessment soil fertility changes under stubble removal and stubble retention in the Loess Plateau where soil is prone to severe erosion. It was indicated that soil $\mathrm{N}$ increased a lot for and two stubble retention treatments had the higher $\mathrm{N}$ balance at the end of two rotations. Soil K balance performed that soil $\mathrm{K}$ was in deficient for all treatments and two stubble retention treatments had lower deficit K. The treatments with stubble retention produced higher grain yields than the stubble removal treatments. It was concluded that stubble retention should be conducted to increase crops productivity, improve soil fertility as well as agriculture sustainability in the Loess plateau, China.
\end{abstract}

\section{Introduction}

Crop stubble is a main agricultural waste material as well as a renewable resource, due to being rich in nitrogen $(\mathrm{N})$, phosphorus $(\mathrm{P})$, and potassium $(\mathrm{K})$. China has a long tradition of efficient recycling of organic residues in agriculture, but this tradition is rapidly disappearing following the intensification of agricultural production, the increased use of mineral fertilizers, and the increasing urbanization and decoupling of crop production and animal production [1]. The intensification of agricultural production has greatly increased the agricultural production, but at the same time, it has contributed to a decrease in resource use efficiency, land degradation through increased wind and water erosion, and pollution of ground water and surface waters [2-4]. There are approximately 0.7 billion ton of organic residues produced each year in China, which contain 3, 0.70, and 7 million ton of $\mathrm{N}, \mathrm{P}$, and $\mathrm{K}$, respectively, equivalent to $25 \%$ of the total chemical fertilizers used for farming system [5].

In the last few decades, there has been increased interest in the reuse of crop stubble for soil ecology $[6,7]$, crop system
$[8,9]$, and atmospheric environment [10] worldwide. Retention of plant residues has been found to have many long-term benefits around the world. These crop stubble constitutes a mulch cover that protects the soil against run-off and erosion [11] and increases the percentage of organic matter in the surface soil layer $[12,13]$. Nutrient loss due to runoff is also decreased [14]. The capacity of the soil surface to intercept rainfall is improved because of changes in soil roughness, soil surface porosity, and hydraulic conductivity of the topsoil. Mulching also reduces temperature extremes $[15,16]$ and direct evaporation $[17,18]$. As a result, crop productivity is often improved. However, according to existing problems of rational and effective utilization of stubble resources under different soils and climatic conditions, the choice of the best suited utilization of stubble must be harmonious to particular agroecological environment.

On the western Loess Plateau in China, dryland cropping systems are dominated by wheat. The practice of 3 ploughs and 2 harrows is employed prior to sowing to prepare a seedbed, while all crop stubble and residues are normally removed from the field at harvest for animal feed or fuel 
for heating or cooking [19]. The combination of continuous cereal cropping, tillage, and stubble removal reduced soil fertility and increased soil erosion on sloping land [20, 21]. However, little research on stubble retention had been undertaken in the semiarid areas on the western Loess Plateau where soil is prone to severe erosion. The objective of the present study was to assess soil fertility changes under stubble removal and stubble retention in the Loess Plateau.

\section{Methods and Materials}

2.1. Site Description. The field experiment was conducted from 2001 to 2009 at the Dingxi Experimental Station $\left(35^{\circ} 28^{\prime} \mathrm{N}, 104^{\circ} 44^{\prime} \mathrm{E}\right.$, elevation $1971 \mathrm{~m}$ a.s.l.) of Gansu Agricultural University, Anding County, Gansu Province, northwest China. The site had a Huangmian soil [22], aligning with a Calcaric Cambisols in the FAO soil map of the world [23]. It is a sandy loam with low fertility. Soil organic carbon was below $7.63 \mathrm{~g} \mathrm{~kg}^{-1}$ (Table 1), representing the major cropping soil in the district [24], one of two dominant soils on the Loess Plateau. Long-term annual rainfall at Dingxi averages $391 \mathrm{~mm}$, ranging from $246 \mathrm{~mm}$ in 1986 to $564 \mathrm{~mm}$ in 2003, with about 54\% received between July and September. Daily maximum temperatures can reach up to $38^{\circ} \mathrm{C}$ in July, while minimum temperatures can drop to $-22^{\circ} \mathrm{C}$ in January. Hence, summers are warm and moist, whereas winters are cold and dry. Annual accumulated temperature $>10^{\circ} \mathrm{C}$ is $2239^{\circ} \mathrm{C}$, and annual radiation is $5929 \mathrm{MJ} \mathrm{m}^{-2}$ with $2477 \mathrm{~h}$ of sunshine. The site had a long history of continuous cropping using conventional tillage. The crop prior to the experiment commencement in 2001 was flax (Linum usitatissimum L.).

2.2. Experimental Design and Treatment Description. The experiment had a fully phased $2 \times 2$ factorial design with 2 phases, replicated 4 times (blocks). Spring wheat (cv. Dingxi no. 35) and field pea (cv. Yannong) were sown in rotation in both phases represented in each year. Phase $1(\mathrm{P} / \mathrm{W})$ started with field pea followed by spring wheat, and phase $2(\mathrm{~W} / \mathrm{P})$ started with spring wheat followed by field pea. Therefore, there were 32 plots in total. Plots were $4 \mathrm{~m}$ wide, $17 \mathrm{~m}$ long in block 1, $21 \mathrm{~m}$ long in blocks 2 and 3, and $20 \mathrm{~m}$ long in block 4 . All treatments were described as follows (Table 2).

2.3. Sowing Rate, Fertilizers, and Field Management. All crops were sown by a small no-till seeder (5-6 rows in $1.2 \mathrm{~m}$ width) designed by the China Agricultural University. The no-till seeder, drawn by a $13.4 \mathrm{~kW}(18 \mathrm{HP})$ tractor, was designed to place fertilizers below the seeds using narrow points followed by concave rubber press wheels in one operation. Spring wheat was sown at $187.5 \mathrm{~kg} \mathrm{ha}^{-1}$ in mid-March and harvested in late July to early August each year. Field pea was sown at $180 \mathrm{~kg} \mathrm{ha}^{-1}$ in early April and harvested in early July each year. The row spacing was $20 \mathrm{~cm}$ for spring wheat and $24 \mathrm{~cm}$ for field pea using the no-till seeder.

Nitrogen and $\mathrm{P}$ were applied at $105 \mathrm{~kg} \mathrm{Nha}^{-1}$ as urea $(46 \% \mathrm{~N})$ and at $45.9 \mathrm{~kg} \mathrm{Pha}^{-1}$ as calcium superphosphate $(6.1 \% \mathrm{P})$ for spring wheat, and $20 \mathrm{~kg} \mathrm{Nha}^{-1}$ and
$45.9 \mathrm{~kg} \mathrm{Pha}^{-1}$ for field pea. No farm manure was used in this experiment. Field peas were not inoculated when sown as no appropriate rhizobia were available on the market. However, the site had history of field pea in the previous 3 years. Roundup (glyphosate, 10\%) was used for weed control during fallow after harvesting as per the product guidelines. During the growing season, weeds were removed by hand. Pests and diseases were monitored and controlled as per conventional practice in the area.

\subsection{Measurements}

2.4.1. Soil Properties. Soil samples were collected from 0$30 \mathrm{~cm}$ depth for the determination of soil nutrient level after harvest (mid-August, 2007). Five cores were bulked into one sample for each plot using a standard $25 \mathrm{~mm}$ diameter soil corer. Soil sample were dried and sieved through $2 \mathrm{~mm}$ mesh. Soil organic carbon was determined by dichromate oxidation [25]. Total $\mathrm{N}$ in soil was determined by Semimicro-Kjeldahl method [26]. Nitrate nitrogen $\left(\mathrm{NO}_{3}{ }^{-}-\mathrm{N}\right)$ and exchangeable ammonium nitrogen $\left(\mathrm{NH}_{4}{ }^{+}-\mathrm{N}\right)$ in soil was determined using $\mathrm{FeSO}_{4} / \mathrm{Zn}$ reduction method described by Carter [27]. Total $\mathrm{P}$ in soil was determined using Sodium carbonate fusion described by Carter [27]. Available phosphorus (P) in soil was determined by extracting samples with $0.5 \mathrm{M} \mathrm{NaHCO}_{3}$, and determining $\mathrm{P}$ colorimetrically using molybdate [28]. Total $\mathrm{K}$ in soil was determined using Flame photometry method [28]. Available $\mathrm{K}$ in soil was determined using $1 \mathrm{~N}$ ammonium acetate extraction-flame photometry method [28]. Nitrogen in grain and crop residues (straw and chaff) was determined using the method described by Lu [29]. Potassium in grain and crop residues (straw and chaff) was determined using the method described by Bao [28].

2.4.2. Nitrogen Fixation. Nitrogen fixation by field pea was estimated in 2005 using the method of ${ }^{15} \mathrm{~N}$ natural abundance as described by Armstrong et al. [30]. At anthesis, 5 individual field pea plants were cut at ground level from each plot, bulked into one sample and dried at $60^{\circ} \mathrm{C}$ for $24 \mathrm{~h}$. At the same time, 5 nonlegume plants (weeds) from the plot were also collected and oven-dried at $60^{\circ} \mathrm{C}$ as "reference plants". Both the legumes and reference plants were ground through $1 \mathrm{~mm}$ mesh, then subsampled and finely ground prior to analysis of ${ }^{15} \mathrm{~N}$ natural abundance using continuous flow isotope ratio mass spectrometry (Europa Scientific ANCA System) [31].

2.4.3. Grain Yield. The whole plot was harvested manually using sickles at $5 \mathrm{~cm}$ above ground. The edges $(0.5 \mathrm{~m})$ of the plot were trimmed and discarded. Samples were then processed to obtain grain yield, straw and chaff. The grain yield from the harvesting area was recorded and converted to yield per hectare.

\subsection{Calculations.}

2.5.1. Nitrogen Balance. Nitrogen balance was calculated over 4 years with two complete rotation cycles. Nitrogen 
TABLE 1: Soil chemical and physical properties at the start of experiment.

\begin{tabular}{lccccccc}
\hline $\begin{array}{l}\text { Depth } \\
(\mathrm{cm})\end{array}$ & $\begin{array}{c}\text { Bulk density } \\
\left(\mathrm{g} \mathrm{cm}^{-3}\right)\end{array}$ & $\begin{array}{c}\text { Organic matter } \\
\left(\mathrm{g} \mathrm{kg}^{-1}\right)\end{array}$ & $\begin{array}{c}\text { Total N } \\
\left(\mathrm{g} \mathrm{kg}^{-1}\right)\end{array}$ & $\begin{array}{c}\text { Total P } \\
\left(\mathrm{g} \mathrm{kg}^{-1}\right)\end{array}$ & $\begin{array}{c}\text { Olsen P } \\
\left(\mathrm{mg} \mathrm{kg}^{-1}\right)\end{array}$ & $\begin{array}{c}\text { Available K } \\
\left(\mathrm{mg} \mathrm{kg}^{-1}\right)\end{array}$ & $\mathrm{pH}$ \\
\hline $0-5$ & 1.29 & 13.15 & 0.85 & 0.83 & 5.81 & 290.09 & 8.30 \\
$5-10$ & 1.23 & 12.86 & 0.87 & 0.84 & 5.02 & 274.00 & 8.40 \\
$10-30$ & 1.32 & 11.95 & 0.78 & 0.79 & 2.14 & 202.47 & 8.30 \\
\hline
\end{tabular}

TABLE 2: Details of treatments used in the long-term conservation tillage experiment.

\begin{tabular}{|c|c|c|}
\hline Code & Treatments & Description \\
\hline $\mathrm{T}$ & Conventional tillage with stubble removed & $\begin{array}{l}\text { Fields were ploughed } 3 \text { times and harrowed twice after harvesting. } \\
\text { The first ploughing was in August immediately after harvesting, the } \\
\text { second and third ploughing were in late August and September, } \\
\text { respectively. The plough depths were } 20 \mathrm{~cm}, 10 \mathrm{~cm} \text {, and } 5 \mathrm{~cm} \text {, } \\
\text { respectively. The field was harrowed after the last cultivation in } \\
\text { September and again in October before the ground was frozen. This } \\
\text { is the typical conventional tillage practice in the Dingxi region. }\end{array}$ \\
\hline NT & No-till with stubble removed & $\begin{array}{l}\text { No-till throughout the life of the experiment. The straw was removed } \\
\text { from the field and used as fuel or feed. }\end{array}$ \\
\hline TS & Conventional tillage with stubble incorporated & $\begin{array}{l}\text { Fields were ploughed and harrowed exactly as for the T treatment ( } 3 \\
\text { passes of plough and } 2 \text { harrows), but with straw incorporated at the } \\
\text { first ploughing. All the straw from the previous crop was returned to } \\
\text { the original plot immediately after threshing and then incorporated } \\
\text { into the ground. }\end{array}$ \\
\hline NTS & No-till with stubble cover & $\begin{array}{l}\text { No-till throughout the life of the experiment. The ground was } \\
\text { covered with the straw of previous crop from August until the } \\
\text { following March. All the straw from previous crop was returned to } \\
\text { the original plot immediately after threshing. }\end{array}$ \\
\hline
\end{tabular}

inputs included $\mathrm{N}$ in fertilizers and $\mathrm{N}$ in seeds. The $\mathrm{N}$ in straw brought into the system $(6.8 \mathrm{t} / \mathrm{ha})$ in 2002 was also taken into account for TS and NTS treatments. Nitrogen output includes grain $\mathrm{N}$ and stubble $\mathrm{N}$ if stubble was removed (e.g., T and NT treatments). Nitrogen fixed by field pea in 20012004 was extrapolated using data in 2005 as no data were available in 2001-2004.

2.5.2. Nitrogen Fixation. Nitrogen fixation by field pea was calculated as follows:

$$
\% \mathrm{Ndfa}=\frac{\left(\delta^{15} \mathrm{~N}_{\text {weeds }}-\delta^{15} \mathrm{~N}_{\text {legume }}\right)}{\left(\delta^{15} \mathrm{~N}_{\text {weeds }}-\beta\right)},
$$

(see [30]), where $\% \mathrm{Ndfa}$ is the percentage of plant total $\mathrm{N}$ derived from fixation, $\delta^{15} \mathrm{~N}_{\text {weeds }}$ is the natural abundance of ${ }^{15} \mathrm{~N}$ in reference plant (weeds), $\delta^{15} \mathrm{~N}_{\text {legume }}$ is the natural abundance of ${ }^{15} \mathrm{~N}$ in legume (field pea), and $\beta$ represents a measure of the isotopic fraction associated with redistribution of $\mathrm{N}$ between roots and shoots.

2.5.3. Potassium Balance. Potassium balance was calculated after 5 years. Potassium inputs included $\mathrm{K}$ in straw and $\mathrm{K}$ in seeds. Potassium output includes grain $\mathrm{K}$ and stubble $\mathrm{K}$ if stubble was removed (e.g., T and NT).

2.6. Data Analysis. Analysis of variance was performed to determine the effects of different stubble management on soil fertility and grain yield. All statistical analyses of data were carried out through the SPSS package.

\section{Results and Discussion}

3.1. The Distribution of Soil Organic Matter and Total Nutrients under Different Stubble Management. Results showed that stubble retention increased soil organic matter at the $0-5 \mathrm{~cm}$ and $10-30 \mathrm{~cm}$ depth significantly $(P<0.01)$, while increased soil organic matter at the $5-10 \mathrm{~cm}$ significantly $(P<0.001)$ after 6 years in W/P rotation sequence (Table 3$)$. In the top $5 \mathrm{~cm}$ depth, soil organic matter under NTS was the highest, while soil organic matter under TS was the highest at lower depths. The pattern for organic matter distribution in the $\mathrm{W} / \mathrm{P}$ rotation sequence was similar to that in the $\mathrm{P} / \mathrm{W}$ rotation sequence. Soil organic matter concentration was relatively uniformly distributed within the $0-30 \mathrm{~cm}$ depth under TS treatment. In contrast, NTS treatment resulted in a significant increase in soil organic matter at the soil surface.

Accumulation of soil organic matter at the soil surface was a result of surface placement of crop residues and a lack of soil disturbance that kept residues isolated from the rest of the soil profile. Decomposition of surfaceplaced residues is often slower than when incorporated in the soil profile $[32,33]$, primarily because of less optimal moisture conditions [34]. The apparent soil organic matter accumulation in stubble retention treatments noted by these results is consistent with the findings of Lao et al. [35] and 
TABLE 3: Soil total nutrients as affected by stubble management in different rotation sequence $\left(\mathrm{g} \mathrm{kg}^{-1}\right)$.

\begin{tabular}{|c|c|c|c|c|c|c|c|c|c|}
\hline \multirow{2}{*}{ Depth $(\mathrm{cm})$} & \multirow{2}{*}{ Treatment } & \multicolumn{4}{|c|}{ Field pea-spring wheat $(\mathrm{P} / \mathrm{W})$} & \multicolumn{4}{|c|}{ Spring wheat-field pea (W/P) } \\
\hline & & Organic matter & Total N & Total P & Total K & Organic matter & Total N & Total P & Total K \\
\hline \multirow{5}{*}{$0-5$} & $\mathrm{~T}$ & $13.90 \pm 0.64$ & $1.00 \pm 0.05$ & $0.85 \pm 0.03$ & $15.08 \pm 0.64$ & $13.30 \pm 0.52$ & $1.00 \pm 0.04$ & $0.90 \pm 0.07$ & $15.58 \pm 0.76$ \\
\hline & NT & $14.01 \pm 0.79$ & $1.05 \pm 0.02$ & $0.90 \pm 0.15$ & $14.61 \pm 0.34$ & $13.78 \pm 1.17$ & $1.04 \pm 0.03$ & $0.96 \pm 0.04$ & $14.48 \pm 0.34$ \\
\hline & TS & $15.26 \pm 0.43$ & $1.09 \pm 0.03$ & $1.06 \pm 0.12$ & $16.31 \pm 0.92$ & $14.56 \pm 0.62$ & $1.09 \pm 0.04$ & $1.07 \pm 0.02$ & $16.36 \pm 0.33$ \\
\hline & NTS & $15.66 \pm 1.12$ & $1.13 \pm 0.02$ & $1.08 \pm 0.04$ & $16.77 \pm 0.35$ & $16.81 \pm 1.50$ & $1.21 \pm 0.11$ & $1.09 \pm 0.03$ & $16.92 \pm 0.14$ \\
\hline & Significant & $* *$ & $*$ & $*$ & $*$ & $* * *$ & $*$ & $* *$ & $* *$ \\
\hline \multirow{5}{*}{$5-10$} & $\mathrm{~T}$ & $13.83 \pm 0.68$ & $0.99 \pm 0.04$ & $0.80 \pm 0.02$ & $15.08 \pm 0.60$ & $13.14 \pm 0.32$ & $0.99 \pm 0.03$ & $0.85 \pm 0.06$ & $14.47 \pm 0.71$ \\
\hline & NT & $14.00 \pm 0.58$ & $1.04 \pm 0.04$ & $0.82 \pm 0.02$ & $14.13 \pm 0.22$ & $13.70 \pm 0.87$ & $1.01 \pm 0.02$ & $0.95 \pm 0.14$ & $13.98 \pm 0.61$ \\
\hline & TS & $15.11 \pm 0.38$ & $1.04 \pm 0.04$ & $1.00 \pm 0.09$ & $15.47 \pm 1.73$ & $14.24 \pm 0.84$ & $1.01 \pm 0.01$ & $0.99 \pm 0.02$ & $15.67 \pm 0.26$ \\
\hline & NTS & $14.78 \pm 0.17$ & $1.07 \pm 0.01$ & $1.02 \pm 0.13$ & $16.17 \pm 0.33$ & $14.94 \pm 0.62$ & $1.12 \pm 0.09$ & $1.03 \pm 0.08$ & $16.31 \pm 0.26$ \\
\hline & Significant & $* * *$ & ns & $*$ & ns & $* * *$ & $*$ & ns & $* *$ \\
\hline \multirow{5}{*}{$10-30$} & $\mathrm{~T}$ & $13.17 \pm 0.79$ & $0.99 \pm 0.04$ & $0.81 \pm 0.06$ & $14.53 \pm 0.40$ & $12.42 \pm 1.09$ & $0.96 \pm 0.06$ & $0.871 \pm 0.03$ & $14.54 \pm 0.48$ \\
\hline & NT & $13.70 \pm 0.82$ & $0.99 \pm 0.03$ & $0.81 \pm 0.05$ & $13.86 \pm 0.43$ & $13.49 \pm 0.48$ & $1.01 \pm 0.05$ & $0.87 \pm 0.12$ & $14.21 \pm 0.37$ \\
\hline & TS & $14.45 \pm 0.59$ & $1.00 \pm 0.03$ & $0.83 \pm 0.04$ & $15.10 \pm 1.05$ & $14.03 \pm 0.91$ & $1.01 \pm 0.03$ & $0.89 \pm 0.02$ & $15.27 \pm 0.85$ \\
\hline & NTS & $14.15 \pm 0.26$ & $1.00 \pm 0.05$ & $0.84 \pm 0.02$ & $15.45 \pm 0.66$ & $13.80 \pm 0.75$ & $1.02 \pm 0.04$ & $0.86 \pm 0.02$ & $15.49 \pm 0.04$ \\
\hline & Significant & $* *$ & $\mathrm{~ns}$ & ns & ns & * & $\mathrm{ns}$ & ns & ns \\
\hline
\end{tabular}

Significant level (ns: not significant; ${ }^{*} P<0.05 ;{ }^{* *} P<0.01{ }^{* * *} P<0.001$ ).

Lin et al. [36]. Sun et al. [7] reported that soil organic matter increased $15.8 \% \sim 18.1 \%, 6.6 \% \sim 10.6 \%$, and $1.3 \% \sim 1.9 \%$ stubble retention compared with straw removal in the $0-10$, $10-20,20-40 \mathrm{~cm}$ depths in Wushan soil after 15 years.

Stubble-induced changes in soil total $\mathrm{N}$ are often directly related to changes in soil organic $C$. This similarity may be related to soil organic matter which could influence nutrient retention and supply [37]. Both stubble retention and notillage increased soil total $\mathrm{N}$ concentration significantly $(P<0.05)$ at the soil surface $0-5 \mathrm{~cm}$ (Table 3$)$, but it was uniformly distributed with depths under $\mathrm{T}$ treatment. In the $5-10 \mathrm{~cm}$, both stubble retention and no-tillage increased soil total $\mathrm{N}$ concentration significantly $(P<0.05)$ in $\mathrm{W} / \mathrm{P}$ rotation sequence, but not in $\mathrm{P} / \mathrm{W}$ rotation sequence. In the $10-30 \mathrm{~cm}$ depths, there was no difference in soil total $\mathrm{N}$ concentration $(P>0.05)$ among stubble management and tillage systems in either rotation sequences. Soil total $\mathrm{N}$ probably contains compounds that are more resistant to decomposition and which consequently can affect $\mathrm{N}$ dynamics in the soil. Reeves et al. [38] reported that under stubble management and no-tillage system, soil $\mathrm{N}$ losses were reduced, but short-term $\mathrm{N}$ availability was also reduced. The higher total $\mathrm{N}$ content associated with stubble retention treatments in this study can also be attributed to a reduction in soil erosion. The amount of soil lost due to soil erosion has been reported as high as $3720 \mathrm{t} \mathrm{km}^{-2}$ year $^{-1}$, rising to maxim of $3720 \mathrm{t} \mathrm{km}^{-2}$ year $^{-1}$, in this area during rainy season (JulySeptember) [21]. The stubble retention treatments leaves crop residues on the soil surface and creates more large size soil aggregates, thus reducing soil erosion and contributing to the higher organic carbon and total $\mathrm{N}$ content in soil. In addition, because stubble yield was different for TS and NTS, the amount of crop stubble returned to the soil should be different as well. Thus, difference in total $\mathrm{N}$ was not only due to difference in disturbance by tillage operations, but also due to difference in the amount of crop residue returned to the soil under TS and NTS.

Unlike soil $\mathrm{C}$ and $\mathrm{N}$, soil $\mathrm{P}$ does not readily undergo oxidation-reduction reactions in the common processes of organic matter decomposition. Total $\mathrm{P}$ concentration was significantly $(P<0.05)$ greater in the top $5 \mathrm{~cm}$ depth of stubble retention treatments in $\mathrm{P} / \mathrm{W}$ rotation sequence, while significantly $(P<0.01)$ greater in the top $5 \mathrm{~cm}$ depth of stubble retention treatments in $W / P$ rotation (Table 3 ). In the $5-10 \mathrm{~cm}$ depth, total $\mathrm{P}$ concentration was significantly $(P<0.05)$ greater in $\mathrm{P} / \mathrm{W}$ rotation sequence, but not in $\mathrm{W} / \mathrm{P}$ rotation sequence. In the $10-30 \mathrm{~cm}$ depths, there was no difference in soil total $\mathrm{P}$ concentration $(P>0.05)$ among residue management and tillage systems in either rotation sequences. NTS had the lowest total P concentration in W/P rotation sequence. Surface application of phosphate fertilizer, immobilization of phosphate fertilizer as well as stubble cover in surface soil may account for this result. It has been proposed that organic matter itself may be considered an important source for $\mathrm{P}$ recycling in the short and long term [39].

Total $\mathrm{K}$ was significantly $(P<0.05)$ greater in the top $5 \mathrm{~cm}$ depth of stubble retention treatments in $\mathrm{P} / \mathrm{W}$ rotation sequence, while significantly $(P<0.01)$ greater in the top $5 \mathrm{~cm}$ depth of stubble retention treatments in $\mathrm{W} / \mathrm{P}$ rotation (Table 3 ). In the second $5 \mathrm{~cm}$, total $\mathrm{K}$ concentration was only significantly $(P<0.01)$ greater in $\mathrm{W} / \mathrm{P}$ rotation sequence, but not in $\mathrm{P} / \mathrm{W}$ rotation sequence. In the $10-$ $30 \mathrm{~cm}$ depth, although NTS and TS showed higher total K concentration, there was no difference $(P>0.05)$ among stubble management and tillage systems in either rotation sequences. This result is due to output of soil $\mathrm{K}$ removed out of cropland with crop straw, which could be returned back to soil by organic material recycling in stubble retention treatments. It has been proposed that straw itself may be 
TABLE 4: Soil available nutrients as affected by stubble management in different rotation sequence $\left(\mathrm{mg} \mathrm{kg}^{-1}\right)$.

\begin{tabular}{|c|c|c|c|c|c|c|c|}
\hline \multirow{2}{*}{ Depth $(\mathrm{cm})$} & \multirow{2}{*}{ Treatment } & \multicolumn{3}{|c|}{$\mathrm{P} / \mathrm{W}$} & \multicolumn{3}{|c|}{$\mathrm{W} / \mathrm{P}$} \\
\hline & & Available N & Available P & Available K & Available N & Available P & Available K \\
\hline \multirow{5}{*}{$0-5$} & $\mathrm{~T}$ & $37.37 \pm 1.77$ & $13.61 \pm 0.84$ & $211.41 \pm 21.28$ & $37.31 \pm 0.94$ & $14.22 \pm 0.82$ & $192.04 \pm 13.02$ \\
\hline & NT & $33.94 \pm 1.97$ & $13.78 \pm 0.55$ & $247.13 \pm 12.49$ & $35.63 \pm 0.90$ & $14.25 \pm 2.50$ & $227.91 \pm 21.18$ \\
\hline & TS & $37.97 \pm 0.92$ & $16.40 \pm 1.34$ & $263.76 \pm 38.74$ & $40.64 \pm 1.82$ & $16.23 \pm 0.76$ & $265.17 \pm 16.01$ \\
\hline & NTS & $37.44 \pm 1.02$ & $18.96 \pm 1.46$ & $280.66 \pm 47.11$ & $40.76 \pm 1.86$ & $18.68 \pm 2.29$ & $286.98 \pm 41.57$ \\
\hline & Significant & ns & $* * *$ & ns & $*$ & $*$ & $*$ \\
\hline \multirow{5}{*}{$5-10$} & $\mathrm{~T}$ & $35.13 \pm 3.02$ & $12.34 \pm 1.10$ & $190.74 \pm 19.19$ & $35.94 \pm 2.25$ & $14.95 \pm 1.02$ & $187.41 \pm 37.75$ \\
\hline & NT & $34.54 \pm 0.99$ & $13.12 \pm 1.45$ & $202.43 \pm 32.17$ & $34.51 \pm 5.88$ & $15.09 \pm 0.89$ & $191.90 \pm 26.75$ \\
\hline & TS & $36.77 \pm 1.84$ & $14.15 \pm 1.38$ & $259.75 \pm 4.02$ & $39.63 \pm 0.98$ & $16.30 \pm 2.22$ & $248.04 \pm 34.31$ \\
\hline & NTS & $34.61 \pm 2.03$ & $16.04 \pm 2.12$ & $262.65 \pm 24.37$ & $37.95 \pm 2.65$ & $16.11 \pm 0.58$ & $265.27 \pm 45.85$ \\
\hline & Significant & ns & $*$ & $*$ & ns & ns & ns \\
\hline \multirow{5}{*}{$10-30$} & $\mathrm{~T}$ & $41.91 \pm 0.09$ & $5.57 \pm 2.34$ & $159.45 \pm 9.27$ & $42.44 \pm 2.61$ & $5.15 \pm 0.65$ & $139.25 \pm 5.39$ \\
\hline & NT & $37.43 \pm 1.95$ & $4.76 \pm 0.72$ & $163.82 \pm 6.59$ & $37.99 \pm 1.00$ & $4.74 \pm 0.56$ & $147.90 \pm 16.71$ \\
\hline & TS & $41.38 \pm 0.98$ & $5.74 \pm 0.39$ & $195.07 \pm 9.71$ & $42.42 \pm 2.46$ & $5.24 \pm 0.38$ & $192.27 \pm 6.81$ \\
\hline & NTS & $37.91 \pm 2.50$ & $5.57 \pm 0.44$ & $202.21 \pm 20.53$ & $40.77 \pm 2.48$ & $4.96 \pm 0.61$ & $202.03 \pm 46.50$ \\
\hline & Significant & $*$ & $\mathrm{~ns}$ & $*$ & $\mathrm{~ns}$ & $\mathrm{~ns}$ & $*$ \\
\hline
\end{tabular}

Significant level (ns: not significant; ${ }^{*} P<0.05 ;{ }^{* *} P<0.01$; ${ }^{* *} P<0.001$ ).

considered an important $\mathrm{K}$ source, which could return back $70 \sim 80 \%$ of soil $\mathrm{K}$ removed from cropland with crop straw [9].

3.2. The Distribution of Soil Available Nutrients under Different Stubble Management. Results showed that soil available $\mathrm{N}$ concentration was higher in the top $5 \mathrm{~cm}$ depth of stubble retention, while higher in the $10-30 \mathrm{~cm}$ depth of stubble removal treatment among residue management and tillage systems in either rotation sequences. However, there were no difference in soil available $\mathrm{N}$ concentration $(P>0.05)$ among stubble management and tillage systems, except for that in the top $5 \mathrm{~cm}$ of W/P rotation sequence and $10-30 \mathrm{~cm}$ of P/W rotation sequence (Table 4 ). In this experiment, available $\mathrm{N}$ referred to nitrate- $\mathrm{N}$ and ammonia-N. Residue retention could reduce gaseous loss by volatilization of ammonia$\mathrm{N}$ arisen from soil alkalinity and increased temperatures $[40,41]$, while denitrification and leach of nitrate- $\mathrm{N}$, on the other hand, could be very serious with a combination of no tillage due to improved soil moisture [42-45].

Available $\mathrm{P}$ concentration was significantly $(P<0.001)$ greater in the top $5 \mathrm{~cm}$ depth of stubble retention treatments in $\mathrm{P} / \mathrm{W}$ rotation sequence, while significantly $(P<0.05)$ greater in the top $5 \mathrm{~cm}$ depth of stubble retention treatments in $\mathrm{W} / \mathrm{P}$ rotation (Table 4$)$. In the $5-10 \mathrm{~cm}$ depth, available $\mathrm{P}$ concentration was significantly $(P<0.05)$ greater in $\mathrm{P} / \mathrm{W}$ rotation sequence, but not in $\mathrm{W} / \mathrm{P}$ rotation sequence. In the $10-30 \mathrm{~cm}$ depths, there was no difference in soil available $\mathrm{P}$ concentration $(P>0.05)$ among residue management and tillage systems in either rotation sequences. Surface application of phosphate fertilizer, immobilization of phosphate fertilizer as well as stubble cover in surface soil may account for this result. P solubility is known to be enhanced by increasing SOM and decreasing $\mathrm{pH}$ in alkaline soils [46] by acidifying the rhizosphere soil. Where crop residues are returned to the soil, an increase in $\mathrm{P}$ availability may occur by decreasing the adsorption of $\mathrm{P}$ to mineral surfaces [47] which complements biologically mediated release of $\mathrm{P}$ to improve crop P status. With time, soil and crop residue management practices that promote organic matter accumulation would be expected to improve P nutrition of crops.

Available $\mathrm{K}$ concentration was only significantly $(P<$ $0.05)$ greater in the top $5 \mathrm{~cm}$ depth of stubble retention treatments in $\mathrm{W} / \mathrm{P}$ rotation sequence, but not in $\mathrm{P} / \mathrm{W}$ rotation sequence (Table 4$)$. In the $5-10 \mathrm{~cm}$, available $\mathrm{K}$ concentration was only significantly $(P<0.05)$ greater in rotation $\mathrm{P} / \mathrm{W}$ sequence, but not in $\mathrm{W} / \mathrm{P}$ rotation sequence. In the $10-30 \mathrm{~cm}$ depth, there was significantly $(P<0.05)$ difference among stubble management in either rotation sequences. Intermediate or final products involving organic acids and $\mathrm{CO}_{2}$ produced by SOM could improve availability of fixed $\mathrm{K}$. Where crop residues are returned to the soil, an increase in $\mathrm{K}$ availability may occur by decreasing the adsorption of $\mathrm{K}$ to clay mineral surfaces [43]. In this case, quality of available nutrients for seasoning crop could be enhanced by residue management and tillage systems, thus ensuring improvement of grain yields [48].

3.3. Soil Nutrient Balance under Different Stubble Management. TS and NTS had higher total $\mathrm{N}$ input than $\mathrm{T}$ and NT due to extra $\mathrm{N}$ from previous straw (Table 5), but no difference between TS and NTS and between T and NT in either rotation sequences. However, the total $\mathrm{N}$ output was significantly $(P<0.01)$ different between treatments in either rotation sequences. The treatments with high harvest dry matter and higher grain yield had more N\% output from the system. However, the most of $\mathrm{N}$ could be returned back to soil by organic material recycling in stubble retention treatments. The $\mathrm{T}$ treatment exported the greatest $\mathrm{N}$ from crop harvest, whereas TS treatment had the lowest over 4 years (Table 5). $\mathrm{N}$ fixation by field pea under different treatments was also significantly $(P<0.001)$ different in 
TABLE 5: Nitrogen balance under different treatments over 4 years $\left(\mathrm{kg} \mathrm{N} \mathrm{ha}^{-1}\right)$.

\begin{tabular}{|c|c|c|c|c|c|c|}
\hline Rotation & Item & $\mathrm{T}$ & NT & TS & NTS & Significant \\
\hline \multirow{4}{*}{$\mathrm{P} / \mathrm{W}$} & Input & 269.00 & 269.00 & 299.37 & 299.37 & - \\
\hline & Fixation & 4.65 & 27.12 & 20.73 & 26.06 & $* * *$ \\
\hline & Output & 183.45 & 167.18 & 139.73 & 159.25 & $* *$ \\
\hline & Balance & 90.20 & 128.94 & 180.37 & 166.18 & $* * *$ \\
\hline \multirow{4}{*}{$\mathrm{W} / \mathrm{P}$} & Input & 269.00 & 269.00 & 299.37 & 299.37 & - \\
\hline & Fixation & 3.42 & 25.63 & 16.90 & 24.89 & $* * *$ \\
\hline & Output & 144.82 & 130.34 & 102.51 & 139.09 & $* *$ \\
\hline & Balance & 127.60 & 164.29 & 213.76 & 185.17 & $* * *$ \\
\hline
\end{tabular}

Significant level $(* P<0.05 ; * * P<0.01 ; * * * P<0.001)$.

TABle 6: Potassium balance under different treatments over 5 years $\left(\mathrm{kg} \mathrm{K} \mathrm{ha}^{-1}\right)$.

\begin{tabular}{|c|c|c|c|c|c|c|}
\hline Rotation & Item & $\mathrm{T}$ & NT & TS & NTS & Significant \\
\hline \multirow{3}{*}{$\mathrm{P} / \mathrm{W}$} & Input & 4.93 & 4.65 & 40.15 & 49.27 & - \\
\hline & Output & 41.88 & 33.01 & 52.48 & 60.52 & $* *$ \\
\hline & Balance & -36.95 & -28.36 & -12.32 & -11.25 & $* *$ \\
\hline \multirow{3}{*}{$\mathrm{W} / \mathrm{P}$} & Input & 0.68 & 0.68 & 14.68 & 19.03 & - \\
\hline & Output & 27.82 & 31.38 & 35.99 & 39.87 & $* *$ \\
\hline & Balance & -27.14 & -30.70 & -21.31 & -20.84 & $* *$ \\
\hline
\end{tabular}

Significant level $(* P<0.05 ; * * P<0.01 ; * * * P<0.001)$.

either rotation sequences (Table 5). As a result, over 4 years all treatments accumulated $\mathrm{N}$ in soils, and there was also significant $(P<0.001)$ difference under different treatments in either rotation sequences (Table 5). Treatments, retained the crop stubble, had high $\mathrm{N}$ balance at the end of two rotation cycles. Therefore, stubble retention could improve soil $\mathrm{N}$ balance year by year. But as a whole, soil $\mathrm{N}$ increased from 2002 to 2005 for both phases, indicating total N fertilizer applied in the field were more than crop needed as evidenced by high $\mathrm{N}$ balance at the end of two rotation cycles. Therefore, it is recommended that stubble retention should be practiced to increase crops productivity and improve soil $\mathrm{N}$ storage and $\mathrm{N}$ fertilizer use should be reduced. High $\mathrm{N}$ input not only increased input costs, but also increased the risk of environmental contamination in the ground water system. In the current research, there was up to $185 \mathrm{~kg} \mathrm{ha}^{-1}$ surplus $\mathrm{N}$ (i.e., W/P rotation sequence) accumulated after two rotation cycles under the current fertilizer regime over the 4 years. It appears to be excellent prospects for reducing current farmer fertilizer $\mathrm{N}$ inputs while maintaining spring wheat yields in all seasons. This is a significant finding as it will directly increase farm profitability with little risk. Considerable savings are likely by adopting optimum fertilizer $\mathrm{N}$ rates. There appear to be no other reports on estimates of $\mathrm{N}$ fixation for the Loess Plateau.

No $\mathrm{K}$ fertilizer and farm manure was applied in this experiment. In $\mathrm{P} / \mathrm{W}$ rotation sequence, total $\mathrm{K}$ input was same for T and NT, but more K input for TS and NTS due to $\mathrm{K}$ input from previous straw. However, total $\mathrm{K}$ output was significantly $(P<0.01)$ different between treatments. The higher harvest dry matter and higher grain yield, the higher $\mathrm{K}$ output from the system. NTS treatment exported the greatest
$\mathrm{K}$ from crop harvest, whereas NT treatment had the lowest $\mathrm{K}$. As a result, there was also significant $(P<0.01)$ different in soil $\mathrm{K}$ balance under different treatments (Table 6). Soil $\mathrm{K}$ balance in $\mathrm{W} / \mathrm{P}$ rotation sequence was similar to that in $\mathrm{P} / \mathrm{W}$ rotation sequence. However, the average $\mathrm{K}$ balance under $\mathrm{T}$ treatment in $\mathrm{W} / \mathrm{P}$ rotation sequence was higher than that in $\mathrm{P} / \mathrm{W}$ rotation sequence, whereas the average $\mathrm{K}$ balance under TS, NT, and NTS treatments in W/P rotation sequence was lower than that in $\mathrm{P} / \mathrm{W}$ rotation sequence. Unlike soil $\mathrm{N}$ balance being in surplus, soil $\mathrm{K}$ was indeficient for all treatments, ranged from $11.25 \mathrm{~kg} \mathrm{Kha}^{-1}$ for the NTS treatment to $36.95 \mathrm{~kg} \mathrm{~K} \mathrm{ha}^{-1}$ for the T treatment (Table 6). Therefore, it is suggested that fertilizer K should be applied to maintain soil $\mathrm{K}$ balance.

3.4. Crop Yield under Different Stubble Management. For spring wheat, the treatments with stubble retention produced more grain yields than the treatments with stubble removed in all 8 years. There were significant differences in grain yield among treatments, except that in 2005, 2006, and 2008 (Table 7). For field pea, there were significant differences among treatments, except that in 2004, 2005, 2008, and 2009. Averaged across 8 years, yield of wheat under the NTS and TS treatment was 21\% $\left(0.344 \mathrm{tha}^{-1}\right)$ and $9 \%\left(0.144 \mathrm{tha}^{-1}\right)$ higher than the T treatment. Similarly, yield of field pea under the NTS and TS treatment was $20 \%\left(0.227 \mathrm{tha}^{-1}\right)$ and $2 \%\left(0.026 \mathrm{tha}^{-1}\right)$ higher than the $\mathrm{T}$ treatment. A recent survey of farmers in the area surrounding the experimental site found average grain yield was just $1.0 \mathrm{tha}^{-1}$ for spring wheat and $0.8 \mathrm{tha}^{-1}$ for field pea in the 2003 season [49]. Corresponding results from the current study for T and NTS were $1.641 \mathrm{tha}^{-1}$ and $1.986 \mathrm{tha}^{-1}$ for 
TABLE 7: Grain yield under different treatments $\left(\mathrm{tha}^{-1}\right)$.

\begin{tabular}{|c|c|c|c|c|c|c|}
\hline Crop & Year & $\mathrm{T}$ & NT & TS & NTS & Significant \\
\hline \multirow{8}{*}{ Spring wheat } & 2002 & $1.816 \pm 0.279$ & $1.414 \pm 0.362$ & $1.736 \pm 0.276$ & $2.151 \pm 0.246$ & $* * *$ \\
\hline & 2003 & $1.416 \pm 0.281$ & $1.545 \pm 0.356$ & $1.646 \pm 0.367$ & $1.825 \pm 0.132$ & $*$ \\
\hline & 2004 & $2.189 \pm 0.248$ & $1.664 \pm 0.219$ & $2.162 \pm 0.221$ & $2.382 \pm 0.304$ & $*$ \\
\hline & 2005 & $2.900 \pm 0.519$ & $3.077 \pm 0.292$ & $2.988 \pm 0.663$ & $3.327 \pm 0.060$ & ns \\
\hline & 2006 & $1.383 \pm 0.210$ & $1.317 \pm 0.200$ & $1.565 \pm 0.235$ & $1.549 \pm 0.123$ & ns \\
\hline & 2007 & $0.562 \pm 0.132$ & $0.633 \pm 0.169$ & $0.666 \pm 0.126$ & $0.944 \pm 0.187$ & $* *$ \\
\hline & 2008 & $1.632 \pm 0.549$ & $1.818 \pm 0.899$ & $1.851 \pm 0.312$ & $2.100 \pm 0.329$ & ns \\
\hline & 2009 & $1.233 \pm 0.371$ & $0.985 \pm 0.644$ & $1.670 \pm 0.325$ & $1.607 \pm 0.383$ & $*$ \\
\hline \multirow{8}{*}{ Field pea } & 2002 & $1.653 \pm 0.177$ & $1.416 \pm 0.275$ & $1.527 \pm 0.313$ & $1.790 \pm 0.213$ & $*$ \\
\hline & 2003 & $0.881 \pm 0.206$ & $0.803 \pm 0.156$ & $0.823 \pm 0.101$ & $1.269 \pm 0.288$ & $* *$ \\
\hline & 2004 & $1.708 \pm 0.145$ & $1.496 \pm 0.440$ & $1.681 \pm 0.349$ & $1.668 \pm 0.193$ & ns \\
\hline & 2005 & $1.686 \pm 0.241$ & $1.816 \pm 0.268$ & $1.911 \pm 0.672$ & $2.119 \pm 0.534$ & ns \\
\hline & 2006 & $0.759 \pm 0.129$ & $0.552 \pm 0.122$ & $0.872 \pm 0.123$ & $0.890 \pm 0.048$ & $* *$ \\
\hline & 2007 & $0.206 \pm 0.023$ & $0.277 \pm 0.067$ & $0.342 \pm 0.053$ & $0.553 \pm 0.088$ & $* * *$ \\
\hline & 2008 & $1.342 \pm 0.196$ & $1.306 \pm 0.387$ & $1.190 \pm 0.486$ & $1.649 \pm 0.180$ & ns \\
\hline & 2009 & $0.762 \pm 0.127$ & $0.727 \pm 0.087$ & $0.857 \pm 0.143$ & $0.873 \pm 0.249$ & ns \\
\hline
\end{tabular}

Significant level (ns: not significant; ${ }^{*} P<0.05 ;{ }^{* *} P<0.01 ;{ }^{* * *} P<0.001$ ).

spring wheat, and $1.125 \mathrm{tha}^{-1}$ and $1.351 \mathrm{tha}^{-1}$ for field pea, respectively. This represents a potential significant improvement in grain yield of 40\% 69\% for field pea and 64\% $99 \%$ for spring wheat through better agronomic practices (e.g., stubble retention). These results were inconsistent with the findings of McCalla and Army [50] who reported that stubble retention decreased yields, especially in a humid climate, due to poor crop establishment under reduced tillage [51]. Graham et al. [52] found that in autumn-sown crops under direct drill, the yields were lower when straw residues were left on the surface than when residues were burnt. Incorporation of straw reduced the detrimental effect of straw on yields, but the yields were lower than those where the straw had been burnt.

\section{Conclusions}

Stubble retention on an alkaline soil in a semiarid areas for several years markedly improved fertility and increased crop productivity. Stubble retention resulted in significantly greater soil organic matter at the $0-30 \mathrm{~cm}$ depth. Stubble retention increased soil total $\mathrm{N}$ significantly at the soil surface $0-5 \mathrm{~cm}$, but soil total $\mathrm{N}$ concentration remained similar at $10-30 \mathrm{~cm}$ for all treatments. Total $\mathrm{P}$ and total $\mathrm{K}$ were significantly greater in the $0-10 \mathrm{~cm}$ depth under stubble retention treatments. There were no difference in soil available $\mathrm{N}$ concentration among stubble management and tillage systems, except that in the top $5 \mathrm{~cm}$ of W/P rotation sequence and $10-30 \mathrm{~cm}$ of $\mathrm{P} / \mathrm{W}$ rotation sequence. Available $\mathrm{P}$ concentration was significantly greater in the top $5 \mathrm{~cm}$ and $5-10 \mathrm{~cm}$ depth. Available K concentration was significantly greater at the $0-30 \mathrm{~cm}$ depth of stubble retention treatments. Soil N increased greatly from 2002 to 2005 for all treatment. The two stubble retention treatments had the higher $\mathrm{N}$ balance at the end of two rotations. Soil $\mathrm{K}$ was indeficient for all treatments with more deficit under two stubble retention treatments. As a result, the treatments with stubble retention produced more grain yields than the treatment with stubble removed in all 8 years. Grain yields were the highest under NTS, but the lowest under NT for both spring wheat (1.986 versus $1.557 \mathrm{tha}^{-1}$ ) and field pea (1.351 versus $\left.1.049 \mathrm{tha}^{-1}\right)$. It was concluded that stubble retention should be practiced to increase crops productivity, improve soil fertility as well as agriculture sustainability in the Loess plateau.

\section{Acknowledgments}

The project was supported by the Australian Centre for International Agricultural Research (no. CIM-1999-094), the Ministry of Science and Technology in China (no. 2006BAD15B06) and National Natural Science Foundation of China (no. 31060178, and no. 40771132). The authors are grateful to land owners, Mr. J. Q. Li, Mr. F. Zhang, Mr. C. L. Guo, and Mr. C. Q. Wu, for allowing them to use their land and their cooperation, and to Mr. Z. Jin who looked after the site. Authors thank the members of their team for help in experiment. Special thanks to all postgraduate and undergraduate students from Gansu Agricultural University who were involved in this project for different periods.

\section{References}

[1] X. Ju, F. Zhang, X. Bao, V. Römheld, and M. Roelcke, "Utilization and management of organic wastes in Chinese agriculture: past, present and perspectives," Science in China. Series C, Life sciences / Chinese Academy of Sciences., vol. 48, pp. 965-979, 2005.

[2] F. S. Zhang, W. Q. Ma, W. F. Zhang, and M. Fan, "Nutrient management in China: from production system to food chain," in Plant Nutrition for Food Security, C. J. Li, F. S. Zhang, A. Doberman et al., Eds., pp. 13-15, Human Health and Environmental Protection, Beijing, China, 2005. 
[3] J. Liu and J. Diamond, "China's environment in a globalizing world," Nature, vol. 435, no. 7046, pp. 1179-1186, 2005.

[4] S. Rozelle, J. Huang, and L. Zhang, "Poverty, population and environmental degradation in China," Food Policy, vol. 22, no. 3, pp. 229-251, 1997.

[5] J. Wang, D. J. Wang, G. Zhang, and C. Wang, "Effects of different nitrogen fertilizer rate with continuous full amount of straw incorporated on paddy soil nutrients," Journal of Soil and Water Conservation, vol. 24, no. 5, pp. 40-44, 2010.

[6] J. A. Ocio, P. C. Brookes, and D. S. Jenkinson, "Field incorporation of straw and its effects on soil microbial biomass and soil inorganic N," Soil Biology and Biochemistry, vol. 23, no. 2, pp. 171-176, 1991.

[7] X. Sun, Q. Liu, D. J. Wang, and B. Zhang, "Effect of long-term application of straw on soil," Fertility Chinese Journal of EcoAgriculture, vol. 16, no. 3, pp. 587-592, 2008.

[8] A. Whitbread, G. Blair, Y. Konboon, R. Lefroy, and K. Naklang, "Managing crop residues, fertilizers and leaf litters to improve soil C, nutrient balances, and the grain yield of rice and wheat cropping systems in Thailand and Australia," Agriculture, Ecosystems and Environment, vol. 100, no. 2-3, pp. 251-263, 2003.

[9] T. De-shui, J. Ji-yun, H. Shao-wen, L. Shu-tian, and H. Ping, "Effect of Long-Term Application of K Fertilizer and Wheat Straw to Soil on Crop Yield and Soil K Under Different Planting Systems," Agricultural Sciences in China, vol. 6, no. 2, pp. 200-207, 2007.

[10] H. K. Kludze and R. D. DeLaune, "Straw application effects on methane and oxygen exchange and growth in rice," Soil Science Society of America Journal, vol. 59, no. 3, pp. 824-830, 1995.

[11] D. M. Freebairn and W. C. Boughton, "Hydrologic effects of crop residue management practices," Australian Journal of Soil Research, vol. 23, no. 1, pp. 23-35, 1985.

[12] A. Roldán, F. Caravaca, M. T. Hernández et al., "No-tillage, crop residue additions, and legume cover cropping effects on soil quality characteristics under maize in Patzcuaro watershed (Mexico)," Soil and Tillage Research, vol. 72, no. 1, pp. 65-73, 2003.

[13] K. Y. Chan and D. P. Heenan, "The effects of stubble burning and tillage on soil carbon sequestration and crop productivity in Southeastern Australia," Soil Use Manage, vol. 21, pp. 427431, 2005.

[14] J. R. Smart and J. M. Bradford, "Conservation tillage corn production for a semiarid, subtropical environment," Agronomy Journal, vol. 91, no. 1, pp. 116-121, 1999.

[15] B. J. Radford, A. J. Key, L. N. Robertson, and G. A. Thomas, "Conservation tillage increases soil water storage, soil animal populations, grain yield, and response to fertilisers in the semi-arid subtropics," Australian Journal of Experimental Agriculture, vol. 35, no. 2, pp. 223-232, 1995.

[16] K. J. Shinners, W. S. Nelson, and R. Wang, "Effects of residuefree band width on soil temperature and water content," Transactions of the American Society of Agricultural Engineers, vol. 37, no. 1, pp. 39-49, 1994.

[17] Z. Y. Liu, C. P. Wang, H. Y. Lu, L. F. Lei, and Y .S. Wu, "The effect of different mulching methods with whole maize straw in dryland on maize yield," Shanxi Agricultural Science, vol. 28, no. 3, pp. 20-22, 2000.

[18] J. L. Steiner, "Tillage and surface residue effects on evaporation from soils," Soil Science Society of America Journal, vol. 53, no. 3, pp. 911-916, 1989.

[19] R. Lal, "Constraints to adopting no-till farming in developing countries," Soil and Tillage Research, vol. 94, no. 1, pp. 1-3, 2007.
[20] T. Fan, B. A. Stewart, W. Yong, L. Junjie, and Z. Guangye, "Long-term fertilization effects on grain yield, water-use efficiency and soil fertility in the dryland of Loess Plateau in China," Agriculture, Ecosystems and Environment, vol. 106, no. 4, pp. 313-329, 2005.

[21] G. Liu, "Soil conservation and sustainable agriculture on the Loess Plateau: challenges and prospects," Ambio, vol. 28, no. 8, pp. 663-668, 1999.

[22] Chinese Soil Taxonomy Cooperative Research Group, Chinese Soil Taxonomy (Revised Proposal), Institute of Soil Science/ Chinese Agricultural, Science and Technology Press, Academic Sinica, Beijing, China, 1995.

[23] FAO, Soil map of the world: revised legend. World Soil Resources Report 60, Food and Agriculture Organization of the United Nations, Rome, Italy, 1990.

[24] Z. Xianmo, L. Yushan, P. Xianglin, and Z. Shuguang, "Soils of the loess region in China," Geoderma, vol. 29, no. 3, pp. 237$255,1983$.

[25] A. Walkley and I. A. Black, "An examination of the Degtjareff method for determining soil organic matter, and a proposed modification of the chromic acid titration method," Soil Science, vol. 37, pp. 29-38, 1934.

[26] J. M. Bremmer and C. S. Mulvaney, "Total nitrogen," in Methods of Soil Analysis_-Part 2. Chemical and Microbiological Properties, C. A. Bluck, Ed., pp. 595-624, American Society of Agronomy, Wis, USA, 1982.

[27] M. R. Carter, Soil Sampling and Methods of Analysis, Lewis Publishers, Boca Raton, Fla, USA, 1993.

[28] S. D. Bao, Analysis on soil agricultural chemistry, China Agricultural Press, Beijing, China, 2000.

[29] R. K. Lu, Methods of Analysis of Soil and Agro-chemistry, China Agricultural Science and Technology Press, Beijing, China, 2000.

[30] E. L. Armstrong, J. S. Pate, and M. J. Unkovich, "Nitrogen balance of field pea crops in south western Australia, studied using the $15 \mathrm{~N}$ natural abundance technique," Australian Journal of Plant Physiology, vol. 21, no. 4, pp. 533-549, 1994.

[31] T. Dawson and Brooks P. D., "Fundamentals of stable isotope chemistry and measurement," in Application of Stable Isotope Techniques to Study Biological Processes and Functioning of Ecosystems, M. J. Unkovich, J. S. Pate, A. M. McNeill, and D. J. Gibbs, Eds., Kluwer Academic, Dodrecht, The Netherlands, 2001.

[32] P. L. Brown and D. D. Dickey, "Losses of wheat straw residue under simulated field conditions," Soil Science Society of America Proceedings, vol. 34, pp. 118-121, 1970.

[33] F. Ghidey and E. E. Alberts, "Residue type and placement effects on decomposition: field study and model evaluation," Transactions of the American Society of Agricultural Engineers, vol. 36, no. 6, pp. 1611-1617, 1993.

[34] A. J. Franzluebbers, M. A. Arshad, and J. A. Ripmeester, "Alterations in canola residue composition during decomposition," Soil Biology and Biochemistry, vol. 28, no. 10-11, pp. 12891295, 1996.

[35] X. R. Lao, W. H. Sun, and Z. Wang, "Effect of matching use of straw and chemical fertilizer on soil fertility," Acta Pedologica Sinica, vol. 40, no. 4, pp. 618-623, 2033.

[36] B. Lin, J. X. Lin, and J. K. Li, “The changes of crop yield and soil fertility with long-term fertilizer application," Plant Nutrition Fertilizer Science, vol. 1, no. 1, pp. 6-18, 1994.

[37] S. C. Brubaker, A. J. Jones, D. T. Lewis, and K. Frank, "Soil properties associated with landscape position," Soil Science Society of America Journal, vol. 57, no. 1, pp. 235-239, 1993. 
[38] M. Reeves, R. Lal, T. Logan, and J. Sigarán, "Soil nitrogen and carbon response to maize cropping system, nitrogen source, and tillage," Soil Science Society of America Journal, vol. 61, no. 5, pp. 1387-1392, 1997.

[39] C. J. Wright and D. C. Coleman, "The effects of disturbance events on labile phosphorus fractions and total organic phosphorus in the southern Appalachians," Soil Science, vol. 164, no. 6, pp. 391-402, 1999.

[40] G. Lian, D. Wang, J. Lin, and D. Yan, "Characteristics of nutrient leaching from paddy field in Taihu Lake area," Chinese Journal of Applied Ecology, vol. 14, no. 11, pp. 1879-1883, 2003.

[41] J. G. Xi and J. B. Zhou, "Leaching and transforming characteristics of urea $\mathrm{N}$ added by different ways of fertigation," Plant Nutrition Fertilizer Science, vol. 9, no. 3, pp. 271-275, 2003.

[42] G. W. Thomas, "Effects of a killed sod mulch on movement and corn yield," Agronomy Journal, vol. 65, pp. 736-739, 1973.

[43] R. L. Blevins, G. W. Thomas, and Cornelius, "Influence of notillage and nitrogen fertilization on soil properties after 5 years of continuous corn," Agronomy Journal, vol. 69, pp. 383-386, 1977.

[44] D. D. Tyler and G. W. Thomas, "Lysimeter measurements of nitrate and chloride losses from soil under conventional and no tillage corn," Journal of Environmental Quality, vol. 6, no. 1, pp. 63-66, 1977.

[45] C. W. Rice and M. S. Smith, "Denitrification in no-till and plowed soils," Soil Science Society of America Journal, vol. 46, no. 6, pp. 1168-1173, 1982.

[46] EL-Baruni and S. R. Olsen, "Effects of manure on solubility of phosphorus in calcareous soils," Soil Science, vol. 112, pp. 219-225, 1979.

[47] T. Ohno and M. S. Erich, "Inhibitory effects of crop residuederived organic ligands on phosphate adsorption kinetics," Journal of Environmental Quality, vol. 26, no. 3, pp. 889-895, 1997.

[48] G. T. Li, Z. J. Zhao, Y. F. Huang, and B. G. Li, "Effect of straw returning on soil nitrogen transformation," Plant Nutrition and Fertilizer Science, vol. 8, no. 2, pp. 162-167, 2002.

[49] S. Nolan, M. Unkovich, S. Yuying, L. Lingling, and W. Bellotti, "Farming systems of the Loess Plateau, Gansu Province, China," Agriculture, Ecosystems and Environment, vol. 124, no. 1-2, pp. 13-23, 2008.

[50] T. M. McCalla and T. J. Army, "Stubble Mulch Farming," Advances in Agronomy, vol. 13, no. C, pp. 125-196, 1961.

[51] F .B. Ellis, J. G. Elliot, F. Pollard, R. Q. Cannell, and B. T. Barnes, "Comparison of direct drilling, reduced cultivation and ploughing on the growth of cereals: 3 . Winter wheat and spring barley on calcareous clay," The Journal of Agriculture Science, vol. 93, pp. 391-401, 1979.

[52] J. P. Graham, F. B. Ellis, and D. G. Christian, "Effects of straw residues on the establishment, growth and yield of autumnsown cereals," Journal of Agriculture Engineering Research, vol. 24, pp. 39-49, 1986. 

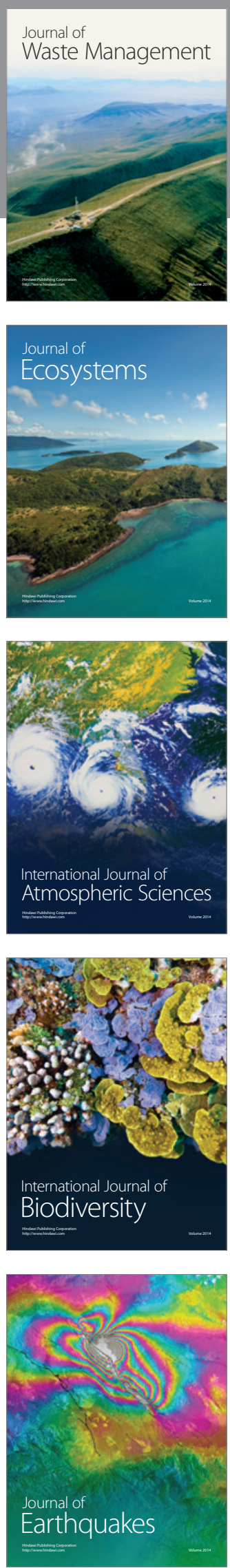
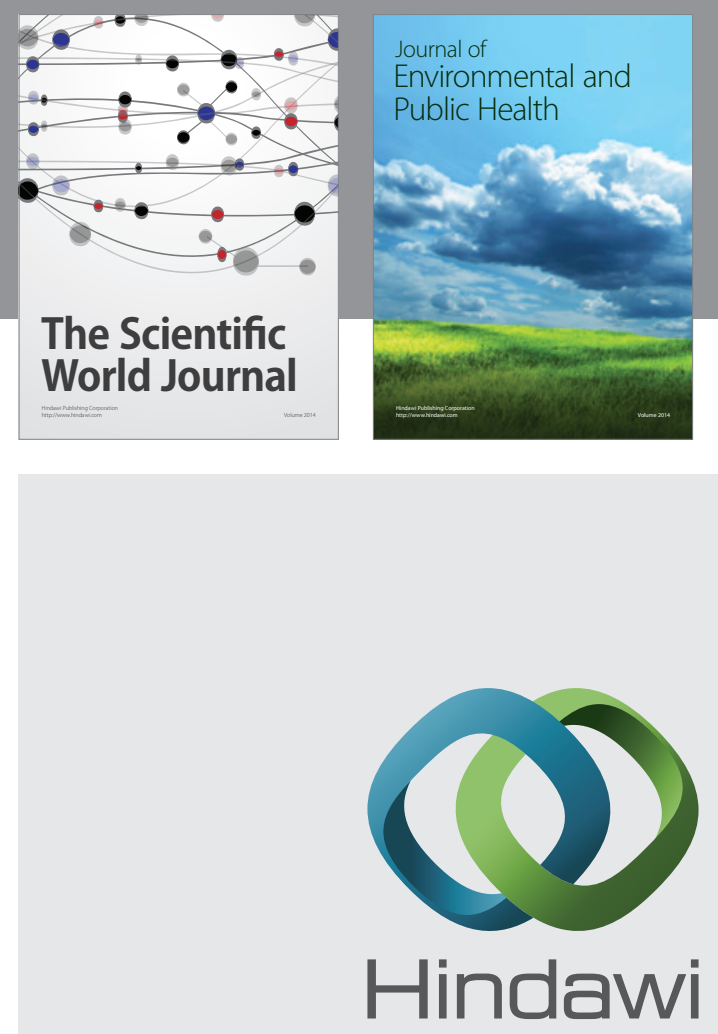

Submit your manuscripts at

http://www.hindawi.com
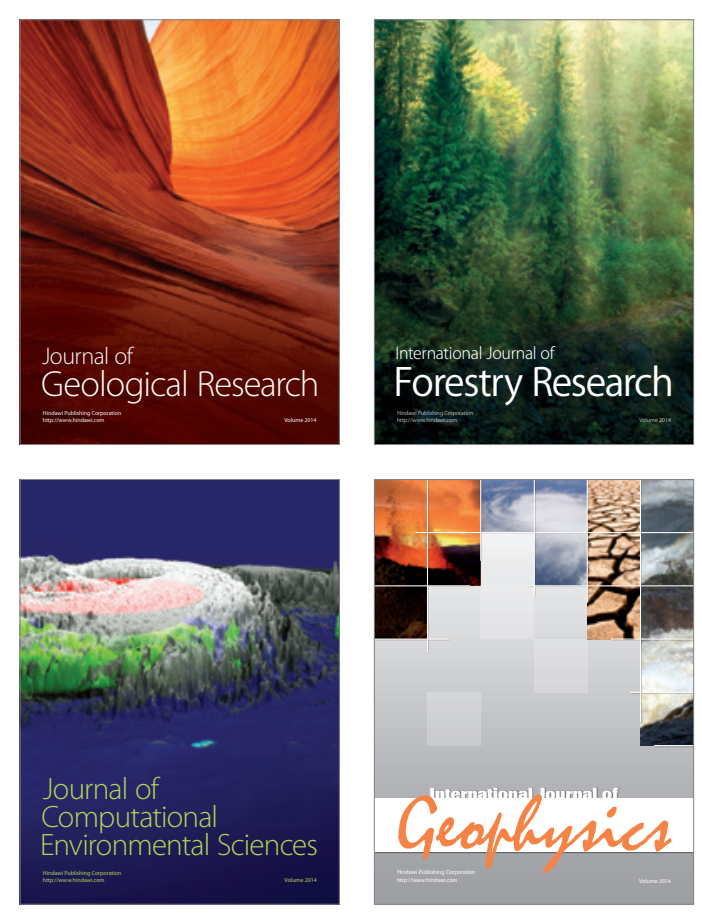
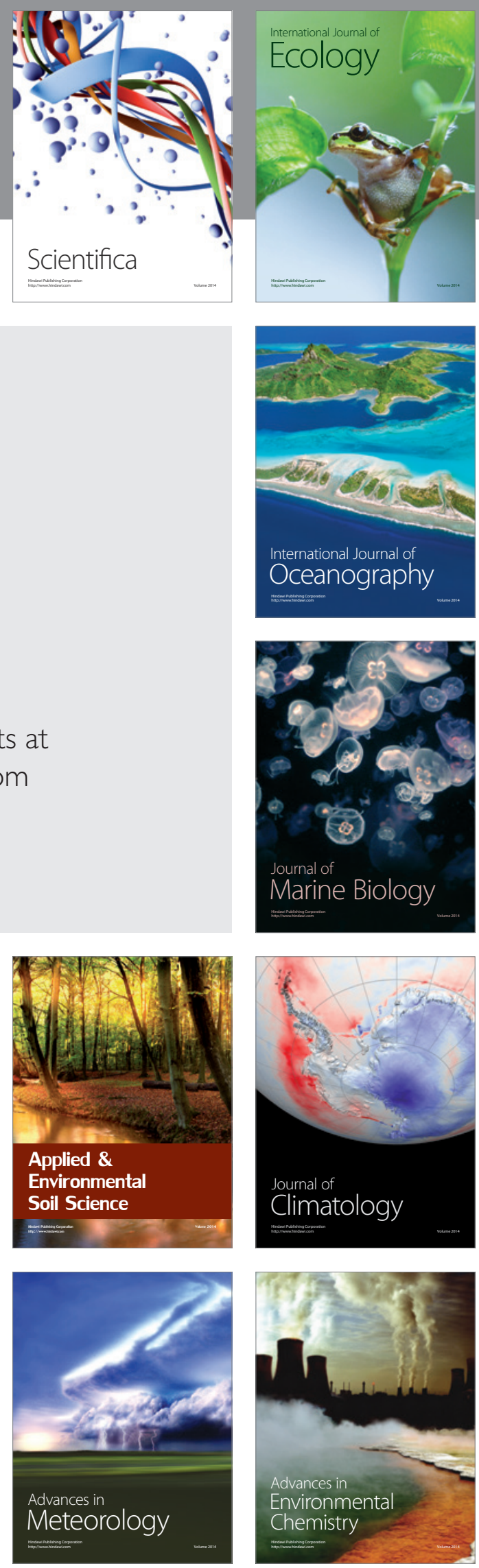